\title{
Antibacterial and Antifungal Activities of Tryptanthrin Derivatives
}

\author{
Jun Kawakami†, Noriyuki Matsushima, Yuta Ogawa, Hiroko Kakinami, \\ Akio Nakane*, Haruo Kitahara**, Masahiko Nagaki and Shunji Ito \\ Graduate School of Science and Technology, Hirosaki University \\ 3 Bunkyo-cho, Hirosaki, Aomori 036-8561, Japan \\ *Graduate School of Medicine, Hirosaki University \\ 5 Zaifu-cho, Hirosaki, Aomori 036-8562, Japan \\ **Department of Chemistry, Faculty of Education, Hirosaki University \\ 1 Bunkyo-cho, Hirosaki, Aomori 036-8560, Japan \\ †Fax: 81-172-39-3541, e-mail: jun@cc.hirosaki-u.ac.jp
}

Tryptanthrin $(\mathbf{T})$ and 13 of its derivatives $\left(\mathbf{T}_{2} \mathbf{N H}_{2}, \mathbf{T 2 C l}, \mathbf{T} 2 \mathrm{Br}, \mathbf{T} 2 \mathrm{NO}_{2}, \mathbf{T 8 O M e}, \mathbf{T 8 M e}, \mathbf{T 8 F}, \mathbf{T 8 B r}, \mathbf{T 8 N O} \mathbf{O}_{2}\right.$, T2NH $80 M e, \mathbf{T}_{2} \mathrm{NH}_{2} 8 \mathrm{NO}_{2}, \mathbf{T} 2 \mathrm{Br8Br}$, and $\mathrm{T}_{2} \mathrm{NO}_{2} 8 \mathrm{NO}_{2}$ ) were synthesized, and their antimicrobial activities against a gram-positive bacterium (methicillin-resistant Staphylococcus aureus, MRSA) and a fungus (Malassezia furfur) were investigated. The antibacterial and antifungal activities were influenced by the substituents on tryptanthrin, with halogen-substituted tryptanthrin derivatives (T2Cl, T2Br, T8F, T8Br, and $\mathbf{T} 2 \mathrm{Br} 8 \mathrm{Br}$ ) showing the highest potency against MRSA and M. furfur.

Key words: Antibacterial activity, Tryptanthrin, MRSA, Malassezia furfur

\section{INTRODUCTION}

Tryptanthrin (T, Fig. 1) is a weakly basic alkaloid found in a number of plant species [1].

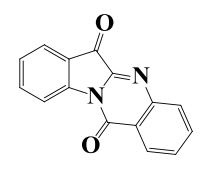

Figure 1. Structure of tryptanthrin $(\mathbf{T})$.

This compound possesses antibacterial and antifungal activities against various pathogenic bacteria and fungi [2]. In particular, the antifungal activity against Malassezia furfur, which is a causative fungus of atopic dermatitis, is important [3]. Tryptanthrin is also effective for the treatment of contact dermatitis (delayed-type allergy) [4]. Therefore, its use as a therapeutic drug for conditions such as atopic dermatitis or in cosmetics is anticipated. However, only a few reports describe the properties of chemosynthetic tryptanthrin derivatives that are not found in nature. In particular, there are few studies regarding the antifungal activities of tryptanthrin derivatives against $M$. furfur [3]. Therefore, we synthesized 13 different tryptanthrin derivatives $\left(\mathbf{T} 2 \mathrm{NH}_{2}, \mathbf{T} 2 \mathrm{Cl}, \mathbf{T} 2 \mathrm{Br}, \mathbf{T}_{2} \mathrm{NO}_{2}, \mathbf{T} 8 \mathrm{OMe}\right.$, T8Me, T8F, T8Br, T8NO $_{2}, \quad$ T2NH $80 M e$, $\mathrm{T}_{2} \mathrm{NH}_{2} \mathrm{SNO}_{2}, \quad \mathrm{~T} 2 \mathrm{Br8Br}$, and $\mathrm{T}_{2} \mathrm{NO}_{2} 8 \mathrm{NO}_{2}$ ) and investigated their antibacterial and antifungal properties against a gram-positive bacterium (methicillin-resistant Staphylococcus aureus, MRSA) and a fungus (M. furfur). The structures are shown in Fig. 2.

Here we report the results of a detailed study of the influence of various substituents on the antibacterial and antifungal activities.

\section{EXPERIMENTAL}

2.1 Synthesis

Tryptanthrin (T) and its 13 derivatives $\left(\mathbf{T} 2 \mathbf{N H}_{2}\right.$,<smiles></smiles><smiles>O=C1C2CCCC2C(=O)C2C1CC1CC(Cl)CCC12</smiles><smiles>O=C1C2CCCC2NC2C(=O)C3C(Br)CCC3CC12</smiles><smiles>O=C1C2CCCC2C(=O)N2C(=O)C3CC([N+](=O)[O-])CCC3NC12</smiles>

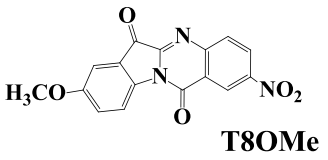<smiles>CC1CC2C(=O)C3CCC(C)(C3)C2C(=O)c2ccccc21</smiles><smiles>O=C1C2CC(F)CC2N2C(=O)c3ccccc3NC12</smiles>

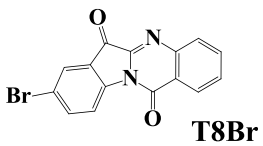<smiles>O=C1C2=CC([N+](=O)[O-])CCC2N2C(=O)C3CCCCC3NC12</smiles>

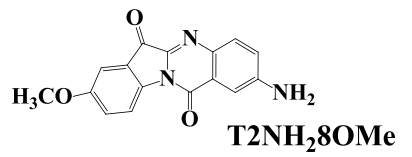<smiles>NO[14C](N)=O</smiles><smiles>O=C1C2CC(Br)CCC2NC2C(=O)C3CC(Br)CC3NC12</smiles><smiles>O=CC1C=C2C(=O)C3NC4CCC([N+](=O)[O-])CC4C(=O)N3C2CC1</smiles>

Figure 2. Structures of the 13 tryptanthrin derivatives.

T2Cl, T2Br, $\mathrm{T}^{2} \mathrm{NO}_{2}, \mathrm{~T} 8 \mathrm{OMe}, \mathrm{T} 8 \mathrm{Me}, \mathrm{T} 8 \mathrm{~F}, \mathrm{~T} 8 \mathrm{Br}$, $\mathrm{T}^{2} \mathrm{NO}_{2}, \mathrm{~T}_{2} \mathrm{NH}_{2} 8 \mathrm{OMe}, \mathrm{T}_{2} \mathrm{NH}_{2} 8 \mathrm{NO}_{2}, \mathrm{~T} 2 \mathrm{Br} 8 \mathrm{Br}$, and T2 $\mathrm{NO}_{2} \mathbf{8} \mathrm{NO}_{2}$ ) were synthesized by the reaction of their corresponding isatin and isatoic anhydride derivatives (Scheme 1) [2]. 


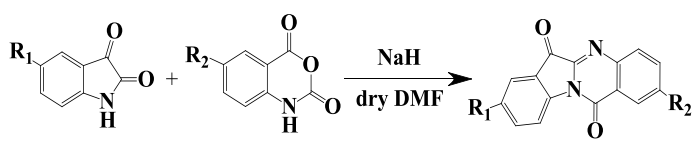

Scheme 1

T: $\mathrm{R}_{1}=\mathrm{H}, \mathrm{R}_{2}=\mathrm{H} ; \mathbf{T} 2 \mathbf{N H}_{2}: \mathrm{R}_{1}=\mathrm{H}, \mathrm{R}_{2}=\mathrm{NH}_{2} ; \mathbf{T} \mathbf{2 C l}: \mathrm{R}_{1}$ $=\mathrm{H}, \mathrm{R}_{2}=\mathrm{Cl}$; T2Br: $\mathrm{R}_{1}=\mathrm{H}, \mathrm{R}_{2}=\mathrm{Br}$; $\mathbf{T} 2 \mathbf{N O}_{2}: \mathrm{R}_{1}=\mathrm{H}$, $\mathrm{R}_{2}=\mathrm{NO}_{2}$; T8OMe: $\mathrm{R}_{1}=\mathrm{OCH}_{3}, \mathrm{R}_{2}=\mathrm{H}$; T8Me: $\mathrm{R}_{1}=$ $\mathrm{CH}_{3}, \mathrm{R}_{2}=\mathrm{H}$; T8F: $\mathrm{R}_{1}=\mathrm{F}, \mathrm{R}_{2}=\mathrm{H}$; T8Br: $\mathrm{R}_{1}=\mathrm{Br}, \mathrm{R}_{2}=$ $\mathrm{H}$; T8NO ${ }_{2}: \mathrm{R}_{1}=\mathrm{NO}_{2}, \mathrm{R}_{2}=\mathrm{H}$; T2NH $\mathbf{N O M e}_{2}: \mathrm{R}_{1}=$ $\mathrm{OCH}_{3}, \mathrm{R}_{2}=\mathrm{NH}_{2} ; \mathbf{T} 2 \mathbf{N H}_{\mathbf{2}} \mathbf{8} \mathbf{N O}_{2}: \mathrm{R}_{1}=\mathrm{NO}_{2}, \mathrm{R}_{2}=\mathrm{NH}_{2}$; T2Br8Br: $\mathrm{R}_{1}=\mathrm{R}_{2}=\mathrm{Br}$; T2NO $\mathbf{N N O}_{2}: \mathrm{R}_{1}=\mathrm{R}_{2}=\mathrm{NO}_{2}$.

We describe the preparation of $\mathbf{T} 2 \mathbf{N H}_{2}$. Other tryptanthrin derivatives were similarly prepared. Under a flow of dry nitrogen, $1.0 \mathrm{~g}(6.8 \mathrm{mmol})$ of isatin in $15 \mathrm{~mL}$ of dry dimethylformamide (DMF) was added over a 15 -min period to $0.16 \mathrm{~g}(6.7 \mathrm{mmol})$ of $\mathrm{NaH}$ with stirring. To the resulting deep purple liquid, $1.3 \mathrm{~g}$ (7.3 $\mathrm{mmol}$ ) of 5-aminoisatoic anhydride in $15 \mathrm{~mL}$ of dry DMF was added with ice cooling over a 30 -min period. The reaction mixture was stirred overnight at room temperature and then quenched with $15 \mathrm{~mL}$ of methanol. The resulting mixture was diluted with $60 \mathrm{~mL}$ of chloroform and washed once with water. The aqueous layer was extracted three times with chloroform, and the combined organic layers were dried (anhydrous sodium sulfate) and concentrated. Crystallization from acetone afforded the pure compound $\mathbf{T} 2 \mathbf{N H}_{2}(1.5 \mathrm{~g})$ in $84 \%$ yield.

T2NH $2:{ }^{1} \mathrm{H}$ NMR $\left(400 \mathrm{MHz}, \mathrm{CDCl}_{3}, \mathrm{Me}_{4} \mathrm{Si}\right) \delta 4.34(2 \mathrm{H}$, s), $7.08-7.92(6 \mathrm{H}, \mathrm{m}), 8.62(1 \mathrm{H}, \mathrm{d}, J=7.6 \mathrm{~Hz})$; FAB-MS: $\mathrm{m} / \mathrm{z} 264\left([\mathrm{M}+\mathrm{H}]^{+}\right)$.

The other analogs were prepared in the same manner. The mass spectra, fast atom bombardment mass analysis (FAB-MS), or electrospray ionization mass analysis (ESI-MS) showed the corresponding molecular ion peaks, and the chemical shifts and the integral ratios of protons were appropriate in the nuclear magnetic resonance analysis ( ${ }^{1} \mathrm{H}$ NMR). The physical data for T, T2Cl, T8Me, T8Br, and $\mathbf{T 8} \mathbf{N O}_{2}$ were identical with the literature values $[2,5,6,7]$.

T2Br: ${ }^{1} \mathrm{H}$ NMR (500 MHz, $\left.\mathrm{CDCl}_{3}, \mathrm{Me}_{4} \mathrm{Si}\right) \delta 7.45(1 \mathrm{H}$, ddd, $J=7.5 \mathrm{~Hz}, J=7.5 \mathrm{~Hz}, J=1.0 \mathrm{~Hz}), 7.81(1 \mathrm{H}$, ddd, $J=8.0 \mathrm{~Hz}, J=7.5 \mathrm{~Hz}, J=1.0 \mathrm{~Hz}), 7.85-8.00(3 \mathrm{H}, \mathrm{m})$, $8.57(1 \mathrm{H}, \mathrm{d}, J=2.3 \mathrm{~Hz}), 8.62(1 \mathrm{H}, \mathrm{d}, J=8.0 \mathrm{~Hz})$; ESI-MS: $m / z 327\left([\mathrm{M}+\mathrm{H}]^{+}\right)$.

T2NO $_{2}:{ }^{1} \mathrm{H}$ NMR $\left(500 \mathrm{MHz}, \mathrm{CDCl}_{3}, \mathrm{Me}_{4} \mathrm{Si}\right) \delta 7.50(1 \mathrm{H}$, $\mathrm{t}, J=7.0 \mathrm{~Hz}), 7.85(1 \mathrm{H}$, ddd, $J=8.0 \mathrm{~Hz}, J=7.0 \mathrm{~Hz}, J=$ $1.0 \mathrm{~Hz}), 7.96(1 \mathrm{H}, \mathrm{d}, J=7.0 \mathrm{~Hz}), 8.60-8.70(2 \mathrm{H}, \mathrm{m})$, $9.29(1 \mathrm{H}, \mathrm{d}, J=2.6 \mathrm{~Hz})$; ESI-MS: $m / z .294\left([\mathrm{M}+\mathrm{H}]^{+}\right)$.

T8OMe: ${ }^{1} \mathrm{H}$ NMR $\left(400 \mathrm{MHz}, \mathrm{CDCl}_{3}, \mathrm{Me}_{4} \mathrm{Si}\right) \delta 3.90(3 \mathrm{H}$, s), 7.20-7.40 $(3 \mathrm{H}, \mathrm{m}), 7.66(1 \mathrm{H}, \mathrm{t}, J=7.5 \mathrm{~Hz}), 7.84(1 \mathrm{H}$, $\mathrm{t}, J=7.5 \mathrm{~Hz}), 8.02(1 \mathrm{H}, \mathrm{d}, J=8.5 \mathrm{~Hz}), 8.43(1 \mathrm{H}, \mathrm{d}, J=$ $7.5 \mathrm{~Hz}), 8.51(1 \mathrm{H}, \mathrm{d}, J=8.5 \mathrm{~Hz})$; FAB-MS: $m / z, 279$ $\left([\mathrm{M}+\mathrm{H}]^{+}\right)$.

T8F: ${ }^{1} \mathrm{H}$ NMR $\left(400 \mathrm{MHz}, \mathrm{CDCl}_{3}, \mathrm{Me}_{4} \mathrm{Si}\right) \delta$ 7.45-7.92 $(4 \mathrm{H}, \mathrm{m}), 8.02(1 \mathrm{H}, \mathrm{d}, J=8.0 \mathrm{~Hz}), 8.42(1 \mathrm{H}, \mathrm{dd}, J=8.0$, $1.5 \mathrm{~Hz}), 8.63(1 \mathrm{H}, \mathrm{dd}, J=8.5,4.0 \mathrm{~Hz})$; FAB-MS: $m / z$ $267\left([\mathrm{M}+\mathrm{H}]^{+}\right)$.

T2NH 8OMe: ${ }^{1} \mathrm{H}$ NMR $\left(500 \mathrm{MHz}, \mathrm{CDCl}_{3}, \mathrm{Me}_{4} \mathrm{Si}\right) \delta$ $3.89(3 \mathrm{H}, \mathrm{s}), 7.09(1 \mathrm{H}, \mathrm{dd}, J=8.5 \mathrm{~Hz}, J=2.6 \mathrm{~Hz}), 7.28$ $(1 \mathrm{H}, \mathrm{d}, J=2.6 \mathrm{~Hz}), 7.36(1 \mathrm{H}, \mathrm{d}, J=2.6 \mathrm{~Hz}), 7.56(1 \mathrm{H}, \mathrm{d}$,
$J=2.6 \mathrm{~Hz}), 7.81(1 \mathrm{H}, \mathrm{d}, J=8.5 \mathrm{~Hz}), 8.5(1 \mathrm{H}, \mathrm{d}, J=8.5$ Hz); FAB-MS: $m / z, 294\left([\mathrm{M}+\mathrm{H}]^{+}\right)$.

T2NH $\mathbf{8 N O}_{2}$ : ${ }^{1} \mathrm{H}$ NMR (500 MHz, dimethyl sulfoxide (DMSO) $\left.-d_{6}, \mathrm{Me}_{4} \mathrm{Si}\right) \delta 6.51(2 \mathrm{H}, \mathrm{s}), 7.14(1 \mathrm{H}, \mathrm{dd}, J=8.5$ $\mathrm{Hz}, J=2.6 \mathrm{~Hz}), 7.43(1 \mathrm{H}, \mathrm{d}, J=2.6 \mathrm{~Hz}), 7.67(1 \mathrm{H}, \mathrm{d}, J$ $=8.5 \mathrm{~Hz}), 8.48-8.50(1 \mathrm{H}, \mathrm{m}), 8.67-8.69(2 \mathrm{H}, \mathrm{m})$; FAB-MS: $m / z 309\left([\mathrm{M}+\mathrm{H}]^{+}\right)$.

T2Br8Br: ${ }^{1} \mathrm{H}$ NMR (500 MHz, $\left.\mathrm{CDCl}_{3}, \mathrm{Me}_{4} \mathrm{Si}\right) \delta 7.85-$ $8.05(4 \mathrm{H}, \mathrm{m}), 8.52(1 \mathrm{H}, \mathrm{d}, J=8.5 \mathrm{~Hz}), 8.56(1 \mathrm{H}, \mathrm{d}, J=$ 2.3Hz); ESI-MS: $m / z, 403\left([\mathrm{M}+\mathrm{H}]^{+}\right)$.

T2NO $_{2}$ SNO $_{2}:{ }^{1} \mathrm{H}$ NMR $\left(500 \mathrm{MHz}, \mathrm{CDCl}_{3}, \mathrm{Me}_{4} \mathrm{Si}\right) \delta$ $8.24(1 \mathrm{H}, \mathrm{d}, J=8.5 \mathrm{~Hz}), 8.65-8.82(3 \mathrm{H}, \mathrm{m}), 8.88(1 \mathrm{H}, \mathrm{d}$, $J=8.5 \mathrm{~Hz}), 8.30(1 \mathrm{H}, \mathrm{d}, J=2.5 \mathrm{~Hz})$; ESI-MS: $m / z 338$ $\left([\mathrm{M}]^{+}\right)$.

\subsection{Antibacterial and antifungal activity test}

Antibacterial and antifungal activities were investigated in vitro on a gram-positive bacterium (MRSA) and a fungus (M. furfur) with the agar plate dilution method described by the Japanese Society of Chemotherapy $[8,9,10,11]$. A bacterial culture (developed overnight for MRSA or over 2-3 days for $M$. furfur) was diluted with the Mueller-Hinton broth (21 $\mathrm{g} / \mathrm{L}$ in distilled water; Becton, Dickinson and Company) for MRSA or malt extract broth $(36 \mathrm{~g} / \mathrm{L}$ in distilled water; Wako Pure Chemical Industries, Ltd.) containing Tween-40 (10 g/L in distilled water; Wako Pure Chemical Industries, Ltd.), monoolein $(2 \mathrm{~g} / \mathrm{L}$ in distilled water; Tokyo Chemical Industry Co., Ltd.), oxgall (20 $\mathrm{g} / \mathrm{L}$ in distilled water; Wako Pure Chemical Industries, Ltd.), peptone (6 $\mathrm{g} / \mathrm{L}$ in distilled water; Wako Pure Chemical Industries, Ltd.), and glycerol ( $2 \mathrm{~g} / \mathrm{L}$ in distilled water; Wako Pure Chemical Industries, Ltd.) for $M$. furfur to a density of $1.0 \times 10^{6}$ colony-forming units $(\mathrm{CFU}) / \mathrm{mL}$. The compounds for testing $(\mathbf{T}$, $\mathrm{T}_{2} \mathrm{NH}_{2}, \mathrm{~T} 2 \mathrm{Cl}, \mathrm{T} 2 \mathrm{Br}, \mathrm{T}_{2} \mathrm{NO}_{2}, \mathrm{~T} 8 \mathrm{OMe}, \mathrm{T} 8 \mathrm{Me}, \mathrm{T} 8 \mathrm{~F}$, T8Br, T8NO $, \mathrm{T}_{2} \mathrm{NH}_{2} 8 \mathrm{OMe}, \mathrm{T}_{2} \mathrm{NH}_{2} 8 \mathrm{NO}_{2}, \mathrm{~T} 2 \mathrm{Br} 8 \mathrm{Br}$, and $\mathbf{T} 2 \mathrm{NO}_{2} \mathbf{8} \mathrm{NO}_{2}$ ) were dissolved in DMSO (Wako Pure Chemical Industries, Ltd.) and diluted with the Mueller-Hinton broth to a concentration of $0.1-100$ $\mu \mathrm{g} / \mathrm{mL}$ for MRSA or with the malt extract broth containing Tween-40, monoolein, oxgall, peptone, and glycerol to a concentration of $4-160 \mu \mathrm{g} / \mathrm{mL}$ for $M$. furfur. Then, each Petri dish was inoculated with the bacterial or fungal suspension and incubated at $37^{\circ} \mathrm{C}$ for $24 \mathrm{~h}$ (for MRSA) or 2-4 days (for $M$. furfur). The lowest concentration at which there was no visible growth was taken as the minimum inhibitory concentration (MIC).

\section{RESULTS AND DISCUSSION}

The antibacterial activities of tryptanthrin $(\mathbf{T})$ and its 13 derivatives $\left(\mathbf{T} 2 \mathbf{N H}_{2}, \mathbf{T} 2 \mathrm{Cl}, \mathbf{T} 2 \mathbf{B r}, \mathbf{T} 2 \mathbf{N O}_{2}, \mathbf{T 8 O M e}\right.$, T8Me, T 8F, T8Br, T8NO, T2 $\mathrm{NH}_{2} 80 \mathrm{Me}$, T2 $\mathrm{NH}_{2} 8 \mathrm{NO}_{2}, \mathrm{~T} 2 \mathrm{Br8Br}$, and $\mathrm{T}_{2} \mathrm{NO}_{2} 8 \mathrm{NO}_{2}$ ) were investigated on a gram-positive bacterium (MRSA) and a fungus ( $M$. furfur) in culture. MICs for MRSA and $M$. furfur are shown in Table. 1. If the MIC value is small, antibacterial and antifungal activities are enhanced. The MIC at which a molecule exerted antimicrobial activity was defined as less than 800 $\mu \mathrm{g} / \mathrm{mL}$ in accordance with the criterion set forth by the Japanese Society of Chemotherapy [9, 10, 11]. Most tryptanthrin derivatives showed very high antibacterial 
activities for MRSA and antifungal activities for $M$. Table 1. Antibacterial activity (MIC) of tryptanthrin (T) and its 13 derivatives $\left(\mathbf{T} 2 \mathbf{N H}_{2}, \mathbf{T 2 C l}, \mathbf{T} 2 \mathbf{B r}, \mathbf{T} 2 \mathbf{N O}_{2}\right.$, T8OMe, T8Me, T8F, T8Br, $\mathrm{TrNO}_{2}$, T2NH $80 \mathrm{Me}$, $\mathrm{T}_{2} \mathrm{NH}_{2} 8 \mathrm{NO}_{2}, \mathbf{T} 2 \mathrm{Br} 8 \mathrm{Br}$, and $\mathrm{T}_{2} \mathrm{NO}_{2} 8 \mathrm{NO}_{2}$ ) against MRSA and $M$. furfur.

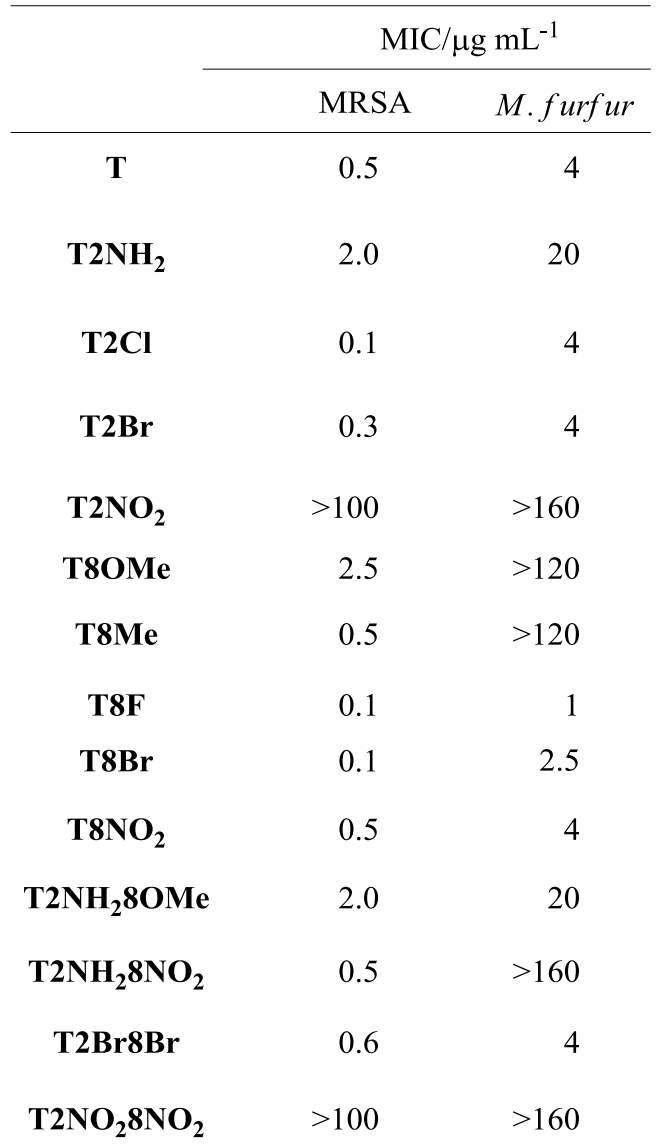

$\overline{\mathrm{MIC}}=$ minimum inhibitory concentration in $\mu \mathrm{g} / \mathrm{mL}$.

furfur. The antibacterial activity for MRSA was higher than the antifungal activity for $M$. furfur. The reason for the greater potency against the gram-positive bacterium (MRSA) compared with that of the fungus ( $M$. furfur) can be attributed to structural differences between the two species. The MIC order for MRSA was $\mathrm{T} 2 \mathrm{Cl}=\mathrm{T} 8 \mathrm{~F}=\mathrm{T} 8 \mathrm{Br}<\mathrm{T} 2 \mathrm{Br}<\mathrm{T}=\mathrm{T} 8 \mathrm{Me}=\mathrm{T}^{2} \mathrm{NO}_{2}=$ $\mathrm{T}_{2} \mathrm{NH}_{2} 8 \mathrm{NO}_{2}<\mathrm{T} 2 \mathrm{Br8Br}<\mathrm{T}_{2} \mathrm{NH}_{2}=\mathrm{T}_{2} \mathrm{NH}_{2} 8 \mathrm{NO}_{2}<$ T8OMe $<$ T2NO 2 , $\mathbf{T} 2 \mathrm{NO}_{2} \mathbf{8} \mathbf{N O}_{2}$, and for $M$. furfur, it was $\mathbf{T 8 F}<\mathbf{T 2 C l}=\mathbf{T 2 B r}=\mathbf{T}_{2} \mathbf{N O}_{2}=\mathbf{T} 2 \mathbf{B r 8 B r}<\mathbf{T}<$ $\mathrm{T}_{2} \mathrm{NH}_{2}=\mathrm{T}_{2} \mathrm{NH}_{2} 80 \mathrm{Me}<\mathrm{T} 8 \mathrm{OMe}, \mathrm{T} 8 \mathrm{Me}, \mathrm{T}_{2} \mathrm{NO}_{2}$, T8Br, $\mathrm{T}_{2} \mathrm{NH}_{2} 8 \mathrm{NO}_{2}, \mathrm{~T}_{2} \mathrm{NO}_{2} 8 \mathrm{NO}_{2}$. For both MRSA and $M$. furfur, antibacterial and antifungal activities of halogen-substituted tryptanthrin derivatives were higher than those of the other tryptanthrin derivatives. Considering the overall efficacy, T8F was the most potent of all the tested compounds with an MIC of 0.1 $\mathrm{mg} / \mathrm{mL}$ for MRSA and $1 \mathrm{mg} / \mathrm{mL}$ for $M$. furfur. In contrast, antibacterial and antifungal activities of $\mathbf{T} 2 \mathbf{N O}_{2}$ and $\mathbf{T} 2 \mathrm{NO}_{2} \mathbf{8} \mathrm{NO}_{2}$, which have a nitro group at position 2 of tryptanthrin, were the lowest. MICs of $\mathbf{T} 2 \mathbf{N O}_{2}$ and $\mathbf{T}_{2} \mathbf{N O}_{2} \mathbf{8 N O}_{2}$ were $>100 \mu \mathrm{g} / \mathrm{mL}$ for MRSA and $>160$ $\mu \mathrm{g} / \mathrm{mL}$ for $M$. furfur. Antibacterial and antifungal activities could be related to electrophilicity of carbonyl carbon of five-membered ring by results of theoretical calculations [12]. Further studies of mechanism for antibacterial and antifungal activities are now in progress. Miconazole nitrate is currently used as a therapeutic drug for treating atopic dermatitis. Its MIC for $M$. furfur, which is a causative fungus of atopic dermatitis, is $c a .25 \mu \mathrm{g} / \mathrm{mL}$. MICs of $\mathbf{T}$ and halogen-substituted tryptanthrin derivatives $\mathbf{T 2 C l}, \mathbf{T} 2 \mathbf{B r}$, T8F, and T2Br8Br for $M$. furfur ranged from 1 to 4 $\mu \mathrm{g} / \mathrm{mL}$, and their antifungal activities were more than six times that of miconazole nitrate. T8F was found to be particularly effective. These results suggest the potential of halogen-substituted tryptanthrin derivatives as therapeutic agents for the treatment of atopic dermatitis.

\section{CONCLUSIONS}

Tryptanthrin (T) and its 13 derivatives $\left(\mathbf{T} 2 \mathbf{N H}_{2}, \mathbf{T} 2 \mathbf{C l}\right.$, $\mathrm{T2Br}, \mathrm{T}_{2} \mathrm{NO}_{2}$, T8OMe, T8Me, T8F, T8Br, $\mathrm{TrNO}_{2}$, T2NH 8 8Me, T2 $\mathrm{NH}_{2} 8 \mathrm{NO}_{2}, \quad \mathrm{~T} 2 \mathrm{Br} 8 \mathrm{Br}, \quad$ and $\mathrm{T}_{2} \mathrm{NO}_{2} \mathbf{8 N O}_{2}$ ) were synthesized, and their antibacterial properties for a gram-positive bacterium (MRSA) and antifungal properties for a fungus ( $M$. furfur) were investigated. Antibacterial and antifungal activities of halogen-substituted tryptanthrin derivatives against MRSA and $M$. furfur were exceptional. The application of these compounds as antibacterial and antifungal agents or antibacterial and antifungal materials will be further investigated.

\section{ACKNOWLEDGMENTS}

The present study was partially supported by a Grant-in-Aid for Scientific Research(C) (No. 22550068) from JSPS and a Grant for Priority Research Designated by the Dean of Graduate School of Science and Technology of Hirosaki University (2008 and 2009). We thank Professor Y. Habata of Toho University for the FAB-MS spectral measurements.

\section{REFERENCES}

[1] A. Witt and J. Bergman, Curr. Org. Chem., 7, 1-19 (2003).

[2] L. A. Mitscher, W. C. Wong, T. De Meulenere, J. Sulko, and S. Drake, Heterocycles, 15, 1017-1019 (1981).

[3] H. Kitahara et al., Japan Patent Pending, 2003, Tokugan 2003-393219, Tokukai 2004-189732.

[4] H. Kitahara e. al., Japan Patent Pending, 2005, Tokugan 2005-59657, Tokukai 2006-241080.

[5] H. Y. Jarrah and V. Thaller, J. Chem. Resarch (S), 186-187 (1980).

[6] T. Hosoe, K. Nozawa, N. Kawahara, K. Fukushima, K. Nishimura, M. Miyaji, and K. Kawai, Mycopathologia, 146, 9-12 (1999).

[7] E. Fiedler, H. -P. Fiedler, A. Gerhard, W Keller-schierlein, W. A. Konig, and H. Zahner, Arch. Microbiol., 107, 249-256 (1976).

[8] M. Nagaki, T. Narita, H. Ichikawa, J. Kawakami, and A. Nakane, Trans. Mater. Res. Soc. of Japan, 36 55-58 (2011).

[9] A. Nagayama, K. Yamaguchi, K. Watanabe, M. Tanaka, I. Kobayashi, and Z Nagasawa, J. Infect. Chemother., 14, 383-392 (2008). 
[10] S. Arakawa, T. Matsui, S. Kamidono, Y. Kawada,

H. Kumon, K. Hirai, T. Hirose, T. Matsumoto, K. Yamaguchi, T. Yoshida, K. Watanabe, K. Ueno, A.

Saito, and T. Teranishi, J. Infect. Chemother., 4, 97-106 (1998).

[11] A. Saito, J. Infect. Chemother., 1, 83-88 (1995).

[12] N. Matsushima, Master Thesis, Hirosaki University, 2011, Hirosaki, Japan.

(Received August 22, 2011; Accepted November 22, 2011) 